\title{
PSIHOTERAPIJSKI TRETMAN ANOREKSIJE NERVOZE U ADOLESCENTNOJ DOBI
}

\section{Sažetak}

Poremećaji hranjenja u adolescenciji su ozbiljan javno zdravstveni problem, jer je njihovo liječenje dugotrajno, kompleksno i zahtjevno, a ishod najčešće neizvjestan. Cilj ovog rada jeste dati kratak pregled dosadašnjih spoznaja o primjeni $i$ efikasnosti psihoterapijskih tretmana kod adolescenata $s$ dijagnosticiranom anoreksijom nervozom. Pokazano je da se u tretmanu ovog poremećaja najčešce primjenjuju kognitivno-bihevioralna, dijalektičkobihevioralna, porodicna, psihoanalitička, kognitivno-analitička $i$ grupna psihoterapija. Sustina svih terapijskih pristupa se prvenstveno ogleda u mijenjaju samodestruktivnih ponašanja koja ugrožavaju život. U skladu sa svojim teorijskim orijentacijama svi tretmani podrazumijevaju specifične mehanizme promjene (kognitivne restrukturacije, promjene $u$ interpersonalnim odnosima, itd) koji se determiniraju u odnosu na postavljene terapijske ciljeve. Na temelju rezultata dosadašnjih istraživanja, zaključuje se da je porodična psihoterapija najefikasnija u tretmanu anoreksije nervoze $u$ adolescentnoj dobi.

Ključne riječi: psihoterapija, poremećaji hranjenja, anoreksija nervoza

\section{UVOD}

Anoreksija nervoza se definira kao ozbiljno i potencijalno smrtonosno stanje obilježeno iskrivljenom slikom tijela i samonametnutim velikim dijetetskim ograničenjima, što obično dovodi do teške pothranjenosti (Kaplan i Sadock, 1998). Radi se o voljnom ograničavanju unosa hrane i aktivnoj težnji za mršavošću uz naglašen ponos kontrolom koju osoba ima nad uzimanjem hrane. Karakteristično je za osobe oboljele od ovog poremećaja hranjenja da imaju normalan osjećaj gladi, ali se užasavaju popuštanja nagonu da jedu (Wenar, 2003).

Garfinkel i Garner (1986), navode da postoje dokazi da je njihova percepcija sitosti izmijenjena, jer izvještavaju da se nakon uzimanja manjih količina hrane osjećaju naduto i mučno. Od uobičajenog držanja 
dijete razlikuje je činjenica da osoba gladuje do opasnog stanja iscrpljenosti, a sve s ciljem postizanja idealne slike mršavosti. Dosadašnja istraživanja pokazuju da prosječna stopa incidencije osoba sa dijagnosticiranom anoreksijom nervozom u općoj populaciji iznosi $0,3 \%$, dok stopa smrtnosti u prvih deset godina nakon njenog dijagnosticiranja iznosi čak 9,6 (Treasure, Schmidt i Furth, 2003). Procijenjeno je da oko 70 miliona ljudi na svijetu ima teškoće vezane za prehranu, a među njima jedna od pet ženskih osoba ima ozbiljne simptome poremećaja hranjenja (Renfrew Center Foundation, 2002).

Najčešće se javlja u dobi od 12 do 18 godina. Prema Vulić-Prtorić (2003), u populaciji adolescenata prevalencija za anoreksiju iznosi $1 \%$ i javlja se uglavnom kod djevojčica, s tim da je odnos između djevojčica i dječaka oko 4:1 u predadolescenciji i 9:1 u adolescenciji.

Za dijagnosticiranje anoreksije nervoze potrebno je prisustvo slijedećih simptoma: odbijanje da se održi tjelesna težina na ili iznad minimalne težine za tjelesnu dob i visinu, izuzetan strah od dobivanja na težini ili debljanja, čak i u slučaju smanjene težine, poremećen način na koji se doživljava težina ili oblik tijela, pretjeran utjecaj težine ili oblika tijela na samoprocjenjivanje ili odbijanje prihvaćanja ozbiljnosti niske tjelesne težine (DSM IV, 1999).

Prilikom dijagnosticiranja ovog poremećaja određuje se i tip anoreksije nervoze, te ona može biti:

a) restriktivnog tipa: da tokom aktualne epizode anoreksije osoba nije imala redovite epizode prejedanja ili da nije izazivala čišćenje crijeva

b) prežderavajućeg/purgativnog tipa: da je osoba prilikom aktualne epizode anoreksije nervoze redovito imala epizode prejedanja ili je izazivala čišćenje crijeva.

Prema Vidović (1998) primarni simptomi koji mogu pomoći prilikom dijagnosticiranja ovog poremećaja u adolescenciji su:

a) gubitak na težini (mršavost) ili odbijanje da se zadrži minimalno primjerena težina u periodu od 10. do 14 . godine (uz odsustvo neke fizičke ili druge psihičke bolesti)

b) prisutnost dvaju ili više simptoma kao što su zaokupljenost unosom kalorija i tjelesnom težinom 
c) promijenjen doživljaj dimenzije vlastitog tijela

d) panični strah od debljanja

e) samoizazivano povraćanje

f) intenzivno vježbanje i čišćenje upotrebom laksativa.

Usljed hormonalnog poremećaja, sekundarni simptom koji se često pojavljuje jeste amenoreja, odnosno izostanak menstruacije u najmanje tri ciklusa.

Dakle, posljedice istrajnog gladovanja, pothranjenost $\mathrm{i}$ njihove komplikacije je neophodno sagledati u kontekstu razvojnog perioda $\mathrm{u}$ kojem se poremećaj javi. U vezi s tim, autori sugeriraju da se $u$ adolescentnom periodu javljaju smetnje rasta, odgoda ili zaustavljanje normalnog obrasca pubertetskog razvoja, osteopenija i osteoporoza (Matsumoto, 2001; Katzman, 2007).

Dosadašnja istraživanja sugeriraju da određene psihološke karakteristike kao što su izrazita usmjerenost na uspjeh (školski uspjeh, sportske aktivnosti..) i perfekcionizam mogu biti značajni prediktori anoreksije nervoze (Begovac, Tomac, Bokić-Sabolić i Pleština, 2013). Pokazano je da su osobe $\mathrm{s}$ anoreksijom nervozom često bojažljive, pesimistične, povučene, ambiciozne, uporne, emocionalno distancirane i imaju nisko samopoštovanje (Hotujac i sur., 2006). Rezultati starijih istraživanja upućuju na značajnu povezanost depresije i introverzije $s$ poremećajima hranjenja (Taylor i Cooper, 1986) Nadalje, pokazano je da $\mathrm{u}$ interpersonalnim odnosima adolescenti s ovim poremećajem pokazuju nesigurnost koja seže do straha od rivaliteta i poricanja zavisti usljed čega se sve više socijalno povlače (Begovac i sur., 2013).

\subsection{Etiološki pristupi anoreksiji nervozi}

Prema Vidić i Jovanović (Čurčić i Erić, 1997), multidimenzionalni etološki model Piazza, Piazza i Rollinsa vrlo slikovito prikazuje kompleksnu interakciju predisponirajućih i precipitirajućih faktora $\mathrm{u}$ razvoju klinički manifestnog poremećaja hranjenja. Ovi autori smatraju da anoreksija ima svoj latentni period koji se proteže kroz cijelo djetinjstvo i manifestni, tj. klinički period, koji pod dejstvom precipitirajućih faktora započinje u adolescenciji. Precipitirajući i predisponirajući faktori, kao i manifestna disfunkcionalnost, zahvataju više nivoa ličnosti: tjelesni, intrapsihički, porodični i socijalni. 
Genetske hipoteze se temelje na podacima da se anoreksija nervoza javlja kod bližih srodnika. Na temelju rezultata transverzalnih istraživanja (prvenstveno na blizancima) pokazano je da se fenotipski i genetski rizik za javljanje ovog poremećaja kod djevojčica može kriti u funkciji hormona jajnika (Culbert, Burt, McGue, Iacono i Klump, 2009; Harden, Mendle i Kretsch, 2012; Klump i sur., 2007; Klump i Culbert, 2007; Klump, Culbert, Edler i Keel, 2008; Silberg i Bulik, 2005). Pojedina istraživanja su isključivo usmjerena na hormon estrogen koji je prije puberteta vrlo malo prisutan kod djevojčica, dok je u periodu puberteta najviše odgovoran za njihove tjelesne promjene, te se njegovo lučenje i djelovanje smatra jednim od osnovnih mehanizama $\mathrm{u}$ genetskom riziku za nastanak anoreksije nervoze (Klump i sur., 2010). Kod dječaka nije potvrđen značajan genetski utjecaj na razvoj anoreksije nervoze (Klump i sur, 2012).

Kulturalne hipoteze se temelje na podacima da anoreksija nije prisutna u područjima u kojima se u okviru određene kulture vitkost ne smatra vrlinom (Ćeranić, 2005).

U svijetlu tradicionalne psihosocijalne teorije se ističe posredujući utjecaj faktora kao što su povećano nezadovoljstvo tijelom i nisko samopoštovanje koji dominiraju u tom razvojnom periodu. S obzirom na značajne promjene u tijelu koje mogu uključivati debljanje, povećana je mogućnost držanja dijeta koje dalje mogu preći u anoreksiju nervozu (Bulik, 2002; Fornari i Danciger, 2003). Međutim, u pregledu dostupne literature nisu nađena istraživanja koja potvrđuju ovu teorijsku pretpostavku. Također, sugerira se da značajnu ulogu za razvoj ovog poremećaja ima neadekvatna porodična klima. Poseban doprinos se pripisuje dominaciji četiri oblika porodične interakcije, a to su pretjerano uplitanje, pretjerano zaštićivanje, rigidnost i odsutnost rješavanja problema (Wenar, 2003). Naglašava se da upravo način na koji neka porodica funkcionira značajno utječe na razvoj nezadovoljstva vlastitim tijelom. Istraživanja potvrđuju da su adolescentice s anoreksijom nervozom, kao i njihove majke, sklone idealizaciji, da imaju teškoće u procesiranju emocija i nesigurnu privrženost (Ward, Ramsey, Turnbull, Steele, Steele I Treasure, 2001). 


\subsection{Tok $i$ ishod anoreksije nervoze}

Kada je riječ o toku i ishodu anoreksije nervoze rezultati dostupnih istraživanja upućuju na podatke da se $50 \%$ osoba sa anoreksijom nervozom u potpunosti oporavi, 30\% njih ima periode oporavka, ali i povratka na uobičajena ponašanja koja su u vezi sa hranom i izgledom, dok se kod $20 \%$ njih problemi koje su specifični za poremećaje hranjenja održavaju tokom cijelog života (Treasure i suradnici, 2003). Smrtnost adolescenata s ovim poremećajem hranjenja iznosi 1,8\% (Striegel-Moore, McMahon, Biro, Schreiber, Craford i Voorhees, 2001; Micali, Hagberg, Peterson i Treasure, 2013).

\subsection{Tretman anoreksije nervoze}

Kriteriji za hospitalizaciju u slučajevima anoreksije su: kada je tjelesna težina pala na manje od $80 \%$ težine očekivane za dob i visinu, u slučajevima dehidracije, znakova kolapsa cirkulacije (nizak krvni pritisak, usporen puls, slaba periferna cirkulacija), kod dugotrajnog povraćanja i povraćanja krvi, kod depresivnog poremećaja raspoloženja i drugih ozbiljnih psihijatrijskih poremećaja (Vidović, 1998).

Što se tiče farmakoterapije, Vidović (1998) navodi kako uloga lijekova u liječenju anoreksije zapravo nije velika, te da se do sada niti jedan lijek nije pokazao značajnim za izlječenje, te se u skladu s tim ponekad upotrebljavaju samo kao dio programa liječenja. Prema navodima ove autorice, najuspješnijom tehnikom liječenja ove bolesti smatra se psihoterapija.

\section{PREGLED REZULTATA ISTRAŽIVANJA O PSIHOTERAPIJSKIM TRETMANIMA ANOREKSIJE NERVOZE U ADOLESCENTNOJ DOBI}

Kako etiologija poremećaja uključuje kombinaciju genetskih i porodičnih faktora (Bulik i suradnici, 2000; Treasure i Holand, 1995), zatim psihološke faktore i osobine ličnosti (Vitousek i Manke, 1994) za efikasnost tretmana je neophodno da se program liječenja prilagodi razvojnoj dobi, te individualnim i specifičnim potrebama svakog adolescenta $u$ njemu. Na temelju dostupne literature opravdano je zaključiti da je tretman anoreksije nervoze kompleksan i zahtjevan, te da iziskuje multidisciplinarni pristup kojim je obuhvaćen somatski i psihoterapijski tretman koji se odvijaju paralelno. $\mathrm{U}$ prilog tome 
svjedoči i podatak da anoreksiju nervozu najčešće prate izražen osjećaj stida, kategorično poricanje teškoća, te smanjen uvid u sopstveno stanje (Hotujac, 2006). Nadalje, otežavajuću okolnost u primjeni bilo kakvih terapijskih intervencija dominantno predstavlja samodestruktivost. Stoga je prvi i najznačajniji cilj svih terapijskih pristupa, spasiti ugroženi život i povratiti pacijentici zdravu tjelesnu težinu (Tadić, 2004). Nakon toga se usmjerava na zalaganje da oboljeli zadrže tu stečenu normalnu težinu. Ovaj drugi po redu cilj podrazumijeva psihološko prilagođavanje, odnosno umanjivanje ili uklanjanje fobije od težine (Vidović, 1998).

\subsection{Kognitivno - bihevioralna terapija (KBT) i evaluacija efikasnosti tretmana}

Divac i Samuel-Lajeunesse (1990) navode da je KBT pristup usmjeren na vraćanje optimalne težine koji je definiran preko idealne težine za spol, visinu i dob, zatim poboljšanje prehrane preko uvođenja optimalnog broja obroka, izbora hrane, njene količine i nutritivnih vrijednosti. U vezi s tim, posebno je značajan proces modifikovanja specifičnih navika vezanih za uzimanje hrane (vrijeme, mjesto, redoslijed i način uzimanja pojedine hrane, obroci u prisustvu drugih, uloga u pripremanju hrane). Nadalje, intervencije idu u smjeru smanjenja ekscesivnih ponašanja koje se odnose na redukciju težine, korigovanje i eliminisanje ponašanja usmjerenih na izbjegavanje uzimanja hrane. Značajan je sistematski rad na modifikovanju ideja vezanih za karakteristike određene hrane kojima se pripisuju kognitivne distorzije vezane za njene efekte.

Kao neizostavan, autori dodaju i sistematski rad na modifikovanju ideja vezanih za oblast tjelesne sheme, formu pojedinih dijelova tijela, perfekcionističke standarde i korigovanje dihotomnog rezonovanja. Za adolescentice sa anoreksijom nervozom su karakteristične disfunkcionalne misli koje proizilaze iz činjenice da sebe doživljavaju drugačijima nego što ih percipira njihova okolina, te su u skladu s njima sklone iracionalnim i disfunkcionalnim interpretacijama i zaključcima. Prema Beck i suradnici (1990), ovakav stil mišljenja često odlikuju kognitivne distorzije tipa ,jedan zalogaj više - znači kilogram više“ (logičke operacije), ,ja sam Neko samo ako sam mršava“ (selektivna apstrakcija), ,kada vidim osobu koja je debela uplašim se da ću postati baš kao ona“ (personalizacija), „debeli ljudi su ružni i nesretni““ 
(pretjerana generalizacija), ,ako nisam u stanju da kontroliram težinu - znači da sam izgubila svu kontrolu“ (razmišljanje tipa sve ili ništa).

Psihopatološka simptomatika anoreksije nervoze koja podrazumijeva odbijanje da se održava normalna tjelesna težina zapravo predstavlja rezultat negativne slike o sebi što potvrđuju i rezultati drugih istraživanja (Beaumont, 2000; Jacobi i sur., 2004). Osim toga, kao posljedice negativnog viđenja sebe javljaju se negativna samoevaluacija, a potom i socijalna introverzija (Lask, 2000).

Nadalje, rezultati nekih studija upućuju na značajnu povezanost između slabije regulacije emocija (sposobnosti da se upravlja emocijama u sebi i prema drugima) i javljanja poremećaja u prehrani, te da manifestiranje simptoma ovih poremećaja predstavlja način da se izbjegnu emocije koje su nelagodne (Mayer, 2001; Schmidt i Treasure, 2006).

Osnovni cilj ovog terapijskog pristupa podrazumijeva modificiranje precijenjene ideje o značaju tjelesnog izgleda i težine, te se u svom radu usmjerava na identificiranje i korigiranje misli koje su ključne kod osoba s anoreksijom nervozom (Fairburn 1997).

Nekoliko istraživanja potvrđuje njegovu uspješnost u liječenju adolescenata oboljelih od anoreksije nervoze (Gardner i Garfinkel, 1997; Pike i suradnici, 2003). Međutim, iako postoje dokazi da KBT ima prednosti pred drugim pristupima, istraživanja usporedne efikasnosti ne upućuju jasno na jednu metodu izbora (Wenar, 2003). U vezi s tim, važno je spomenuti da je procjenjivanje relativne efikasnosti određenog tretmana otežano radi eventualnog preklapanja određenih psihoterapijskih pristupa.

\subsection{Dijalektičko - bihevioralna terapija (DBT) i evaluacija efikasnosti tretmana}

Navedeni terapijski pristup podrazumijeva jednu vrstu kognitivno bihevioralne psihoterapije. Primarno je usmjerena na učenje pravilnog ponašanja kako bi se bolje tolerisao stres i na lakši način regulisale emocije, a time poboljšali odnosi sa drugim ljudima. Cilj je da osoba s anoreksijom nervozom prihvati ono što jeste, ali istovremeno da čini određene promjene u svom načinu razmišljanja i ponašanja. Rezultati dosadašnjih studija upućuju na efikasnost spomenutog tretmana kod tretiranja graničnog poremećaja ličnosti u ženskoj populaciji (Treasure 
i sur., 2003). Pokazano je da može biti koristan u psihoterapijskom tretmanu za osobe kod kojih je uz osnovnu dijagnozu anoreksije prisutan komorbidni granični poremećaj ličnosti (Treasure i sur., 2003).

\subsection{Porodična psihoterapija i evaluacija efikasnosti tretmana}

Primjena porodične psihoterapije kod osoba s dijagnosticiranom anoreksijom nervozom ima za cilj restruktuiranje porodičnih interakcija kako bi se prekinuo model uplitanja i rigidnosti, te potaknula autonomija i fleksibilnost (Wenar, 2003). S obzirom da centralnu ulogu u razvoju, ali i savladavanju ovog poremećaja ima porodica oboljele osobe, uključenost svih njenih članova u tretman je od neupitne važnosti (Monteleone i sur., 2005). Prvi susret se obično odvija po tipu „seanse za ručkom" gdje se opservira kako se članovi porodice organiziraju oko teškoća vezanih za ishranu i na koji ih način pojačavaju, što je zapravo izazov porodičnom mitu da bolest pripada jedino pacijentu/ici (Tadić, 2004). Sa stanovišta cirkularnog koncepta funkcioniranja porodice, simptom je pod utjecajem porodične interakcije $\mathrm{i}$ istovremeno utječe na nju. Ovdje je osnovna uloga simptoma zapravo podržavanje porodične ravnoteže, jer se time u centar dešavanja stavlja simptom, a zaobilaze prvobitni porodični konflikti koji stavljaju obitelj u status quo. Upravo iz tog razloga $\mathrm{u}$ ovom terapijskom procesu zadatak je otkloniti preokupaciju roditelja sa simptoma koje manifestira njihovo dijete i to sa krajnjim ciljem da $\mathrm{i}$ to dijete što prije napusti taj simptom (Tadić, 2004).

Najveći broj autora ukazuje na uspješnost upravo ovog terapijskog pristupa (Couturier i Lock, 2006; Eisler, Simic, Russel i Dare, 2007; le Grange, 2008; Lock i suradnici, 2001; Rhodes, Brown i Madden, 2009; Scholz, 2005). O tome posebno svjedoče istraživanja koja upućuju na terapijski uspjeh kod osoba kod kojih su se poremećaji hranjenja javili u ranijoj dobi i kod kojih nije bilo kroničnog toka bolesti, tj. ako anoreksija nervoza nije trajala više od tri godine. Međutim, postoje i podaci koji sugeriraju da porodična psihoterapija nije pogodna ako su roditelji u procesu razvoda, ako je adolescent/ica već u fazi napuštanja porodice i ako u porodici preovladava neprijateljstvo prema oboljelim bez kompezatorne topline i strpljivosti. U tim slučajevima se kao tretman izbora preporučuje individualna psihoterapija (Tadić, 2004). 
Posebna vrsta psihoterapijskog tretmana anoreksije nervoze koja je namijenjena adolescentima jeste Maudsley porodična psihoterapija nazvana po istoimenoj bolnici u kojoj je osnovan ovaj pristup. Svoju efikasnost najviše je pokazala na osobama kod kojih je bolest trajala manje od tri godine i one koje su imale manje od 18 godina (Lock, 2011). Provodi se u tri jasno definirane faze. Prva je faza obnavljanja tjelesne težine, gdje se akcenat stavlja na procjenu porodičnih tipičnih interakcija i prehrambenih navika. U ovoj se fazi terapeut usmjerava na potencijalne opasnosti pothranjenosti kao što su hipotermija, poremećaj hormona rasta, srčane disfunkcije, kognitivne i emocionalne promjene. U mukotrpnoj borbi za obnavljanje tjelesne težine koju je adolescent imao prije poremećaja, kao i njegov povratak na normalan razvojni put koji je neopterećen smetnjama iz kruga poremećaja hranjenja, terapeut se udružuje s roditeljima (Lock i sur., 2001).

Jedan od osnovnih ciljeva jeste spriječiti dugotrajne hospitalizacije adolescenata tako što će se njihovi roditelji aktivno uključiti u proces njihovog izlječenja. Druga faza Maudsley tretmana je vraćanje kontrole adolescenta nad jelom u kojoj je zadatak roditelja da pozitivno potiču tu kontrolu, te da organiziraju zajedničke obroke. Također se potiču da na adekvatan način razriješe odnose unutar porodičnog sistema, jer se polazi od pretpostavke da minimiziranje napetosti u porodici ohrabruje vraćanje kontrole nad jelom. Treća faza je uspostavljanje zdravog identiteta koja nastaje je adolescent spreman da održava težinu oko 95\% od svoje idealne težine (Le Grange i Eisler, 2009; Le Grange i Lock, 2005). Istraživanja koja su se bavila evaluacijom efikasnosti ovog tretmana pružaju optimistične rezultate. Praćenjem adolescenata tokom pet godina od podvrgavanja Maudsley porodičnom tretmanu utvrđeno je da se čak 75 do $95 \%$ adolescenata u potpunosti oporavi (Eisler i sur., 1997).

\subsection{Psihoanalitička psihoterapija i evaluacija efikasnosti tretmana}

Psihodinamski terapijski pristup se temelji na teorijskim shvatanjima prema koja naglašavaju značaj ranih interakcija s roditeljima $i$ to prvenstveno s majkom, kao i njene patološke modalitete koji se često nalaze $\mathrm{u}$ anamnezama djece $\mathrm{i}$ mladih $\mathrm{s}$ poremećajima hranjenja (Ćeranić, 2005). Upravo iz tih razloga terapijski proces je fokusiran na stvaranje adekvatnog terapijskog odnosa između terapeuta i klijenata $\mathrm{u}$ kojem se na određen način ponavlja sve ono što je klijent tokom svog 
psihičkog razvoja stekao kao iskustvo iz odnosa sa drugim ljudima, a posebno u najranijoj razvojnoj dobi (Vidović, 1998). Nakon uspješnog bavljenja ponašanjem koje ugrožava život i početnog simptomatskog poboljšanja, pomenuti terapijski pristup se posvećuje mijenjanjem pravih uzroka smetnje, koji se kreću u interakciji na razini pojedinac njegova porodica, te na koncu ima zadatak poticanje osamostaljivanja adolescenata, njihove separacije od porodice i učvršćivanje njihovog ličnog integriteta (Tadić, 2004). Smatra se da su unutar porodice osoba koje su oboljele od anoreksije nervoze prisutni latentni sukobi. To su sukobi u relacijama između majke i oca uz mnogo prikrivene agresije, ali su češće prisutni sukobi u relacijama između majke i kćerke (Vidović, 1998; Vidović, Majić i Begovac, 2008). U vezi s tim, sugerira se da anoreksija više ukazuje na interpersonalne nego na individualne probleme (Šeparović Lisak i Marčinko, 2013). Prema psihoanalitičkom pristupu neophodne su hospitalizacije kako bi se adolescenti odvojili od odraslih, te je u skladu s temeljnim psihodinamskim obilježjima $u$ tretmanu vodeća uloga terapeuta. Pregledom dostupne literature ne nalaze se istraživanja koja su obuhvatila evauaciju efikasnosti ovog psihoterapijskog pristupa $u$ liječenju anoreksije nervoze $u$ adolescentnoj dobi.

\subsection{Kognitivno - analitička terapija (CAT) i evaluacija efikasnosti tretmana}

Neki terapeuti primjenjuju kognitivno - analitičku terapiju koja je relativno novijeg datuma, a karakteristična je po tome što kombinira kognitivni i psihoanalitički psihoterapijski pristup, omogućavajući zadovoljavajuće rezultate $\mathrm{u}$ tretmanu osoba kod kojih se anoreksija nervoza javlja u komorbiditetu sa graničnim poremećajem ličnosti. U pregledu dostupne literature se navodi da je malo empirijskih studija koje pružaju podatke o evaluaciji efikasnosti ovog pristupa. U studijama koje su uspoređivale kognitivno-analitički terapijski pristup sa porodičnom, psihodinamskom i suportivnom terapijom zaključeno je da je efikasnija od suportivne psihoterapije, ali da nema značajne razlike između nje i porodične ili psihoanalitičke psihoterapije (Treasure i sur., 2003). 


\subsection{Grupna psihoterapija i evaluacija efikasnosti tretmana}

Kao tretman izbora za poremećaje hranjenja prisutan je i grupni tretman koji može pomoći adolescenticama da podijele svoje probleme $\mathrm{s}$ drugima poput njih, bez opasnosti i straha da će terapeut biti samo još jedna kontrolirajuća odrasla osoba, kao što su to njihovi roditelji (Wenar, 2003). Ipak, neki autori navode da se pokazalo da prilikom primjene ovog tretmana može doći do razvijanja kompetitivne socijalne klime u grupi pri čemu svaka pacijentica nastoji da bude mršavija od svih drugih (Ćeranić, 2005).

\subsection{Poređenje između različitih vrsta psihoterapije}

Pokazano je da nema značajne razlike u efikasnosti kod primjene kratke i dugoročne porodične psihoterapije kod adolescenata s anoreksijom nervozom (Lock, Agras, Bryson i Kraemer, 2005). McIntosh i suradnici (2005) su usporedili efikasnost tri različite vrste psihoterapije u istraživanju koje je obuhvatilo 56 žena starosne dobi od 17 do 40 godina, te je utvrđeno da su se nespecifične supotivne kliničke metode za savladavanje ovog poremećaja pokazale najefikasnije. Ove metode su uključivale psihoedukacije i suportivnu psihoterapiju s akcentom na razvoj adekvatnog terapijskog odnosa. Primjena kognitivnobihevioralne i interpersonalne psihoterapije se također pokazala efikasnom, ali su se značajno efikasnijim od njih pokazali faktori poput dobro uspostavljenog terapijskog odnosa, empatije, pozitivnog stava, te podrške koju su oboljele dobile u okviru nespecifične suportivne kliničke metode. Iako radi starosne dobi uzorka u potpunosti ne odgovara kriterijima uključivanja u ovaj rad, moramo uzeti u obzir činjenicu da se radi o prvoj randomiziranoj i kontroliranoj studiji u ovom području.

Značajno je spomenuti da neka istraživanja upućuju da u adolescentnoj dobi tretiranje ovog poremećaja (u akutnom stadiju) psihoterapijom koja se zasniva na verbalnim metodama, uopće ne daje željene rezultate. Ovo se posebno odnosi na primjenu tradicionalne grupne psihoterapije. U vezi s tim, pokazano je da primjena integrativnog modela koji podrazumijeva kombinaciju psihodrame, art i verbalne psihoterapije daju mnogo bolje rezultate (Diamond-Raab, i OrrellVallente, 2002). 


\section{ZAKLJUČAK}

Anoreksija nervoza podrazumijeva kompleksan mentalno uvjetovan poremećaj hranjenja za kojeg je značajno primarno rješavanje emocionalnih problema koji se nalaze u njegovoj pozadini. Ovo je posebno bitno kada se navedeni poremećaj javi u afektivno turbolentnom razvojnom periodu kakav je adolescentni. Općenito, dva su osnovna pristupa liječenju anoreksije nervoze $\mathrm{i}$ to jedan koji je usmjeren na tijelo (obnavljanje i dostizanje optimalne tjelesne težine), a drugi koji je usmjeren na duh (emocionalni svijet) adolescenta.

Kada aktualnu problematiku sagledamo kroz prizmu pregleda dosadašnjih istraživanja dolazimo do zaključka da tretiranje ovog poremećaja zahtjeva individualan klinički pristup koji mora biti sveobuhvatan, te prilagoditi se potrebama i zahtjevima svakog oboljelog adolescenta. U prilog tome svjedoče i gore navedeni podaci o efikasnosti pojedinih tretmana, kao i činjenica da se interpretacije različitih terapijskih pristupa međusobno ne isključuju, nego se međusobno nadopunjavaju, te $\mathrm{u}$ dobro promišljenoj kombinaciji mogu da doprinesu efikasnosti integralnog plana tretmana. Na početku svake psihoterapije posebna pažnja se posvećuje uspostavljanju adekvatnog terapijskog odnosa. Naglašava se da je prioritet u liječenju regresivnih osoba kakve su osobe s anoreksijom nervozom potaknuti porast tjelesne težine, steći zdrave navike hranjenja, te olakšati tjelesni i emocionalni oporavak. Neki terapijski pristupi zagovaraju ambulantno liječenje ovog poremećaja, dok drugi više nade polažu u hospitalizacije. $\mathrm{Na}$ temelju dosadašnjih istraživanja zaključuje se da je efikasnije ambulantno liječenje, osim u slučajevima teške pothranjenosti kada je adolescentu ugrožen život (Mrzola, Nasser, Hashim, Shih i Kaye, 2013).

Najveći broj dosadašnjih istraživanja koja su se bavila evaluacijom efikasnosti psihoterapijskih tretmana anoreksije nervoze $u$ adolescentnoj dobi potvrđuju efikasnost porodične psihoterapije. Danas se sve više smatra da je Maudsley porodična psihoterapija jedini efikasni psihoterapijski pristup u liječenju anoreksije nervoze kod adolescenata. Iz toga proizilaze preporuke da se buduća istraživanja usmjere na potvrđivanje njene efikasnosti na većim uzorcima, bolje kontroliranim uvjetima i longitudinalnim praćenjem. Nadalje, s obzirom na kompleksnost i zahtjevnost liječenja anoreksije nervoze 
neophodno je $\mathrm{u}$ istraživanju sagledati odnos ovog poremećaja sa potencijalnim komorbiditetom. U vezi s tim, autori sugeriraju da je kod nekih djevojčica u ranoj adolesenciji anoreksija nervoza bila povezana sa Aspergerovim poremećajem (Dudova, Kocurkova i Koutek, 2015).

Bitno je spomenuti da značajan broj dosadašnjih istraživanja obuhvata uzorak iz odrasle ili mješovite populaciju (odrasli i adolescenti), dok je manji broj empirijskih potkrijepljenja o efikasnosti psihoterapije posvećen isključivo adolescentima kojima je dijagnosticiran ovaj poremećaj.

$\mathrm{Na}$ temelju navedenih rezultata dosadašnjih istraživanja $u$ ovom području, zaključuje se da je upravo u ovoj nadasve afektivno turbolentnoj razvojnoj dobi neophodno razviti strategiju kako primarne, tako sekundarne i tercijarne prevencije ovog poremećaja kako bi se na jasno struktuiran način doprinijelo efikasnosti nošenja sa ovom podmuklom i teško liječivom bolešću.

Pravovremenim otkrivanjem smetnji iz kruga ovog poremećaja vulnerabilnim adolescentima se može omogućiti i pravovremeno uključivanje u psihoterapijsko liječenje čime se povećava efikasnost korištenih pristupa, a samim tim i prevenira prelazak bolesti u kronično stanje.

\section{LITERATURA}

1. Američka psihijatrijska udruga (1999). Dijagnostički kriteriji iz DSM IV: međunarodna verzija sa MKB-10 šiframa. Jastrebarsko: Naklada Slap.

2. Beumont P. J. V. (2002). Clinical presentation of anorexia nervosa and bulimia nervosa. In C.G. Fairburn i K. D. Brownell (Eds), Eating Disorders and Obesity A Comprehensive Handbook (pp. 162171). New York: The Guilford Press.

3. Bulik, C.M. (2002). Eating disorders in adolescents and young adults. Child Adolescent Psychiatric Clinical N Am., 11, 201-218.

4. Bulik, C. M., Sullivan, P. F., Wade, T. D., i Kendler, K. S. (2000). Twin studies of eating disorders: A review. International Journal of Eating Disorders, 27, 2-20.

5. Couturier, J. i Lock, J. (2006). What constitutes remission in adolecent anorexia nervosa: a review of various conceptualizations 
and a quantitative analysis. International Journal Eating Disorders, 39, $175-183$.

6. Culbert, K.M., Burt, S.A., McGue, M., Iacono, W.G. i Klump, K.L. (2009). Puberty and the genetic diathesis of disordered eating attitudes and behaviors. Journal of Abnormal Psychology, 118, 788796.

7. Diamond-Raab, L. i Orrell-Vallente, J.K., (2002). Art therapy, psychodrama, and verbal therapy. An integrative model of group therapy in the treatment of adolescents with anorexia nervosa and bulimia nervosa. Child \& Adolescent Psychiatric Clinics of North America, 11, 343-364.

8. Divac, S. i Samuel - Lajeunesse, B. (1990). Mentalna anoreksija: bihevioralno - kognitivni model. Poglavlje u knjizi: Praktikum iz kognitivne i bihevioralne terapije III. Zagreb: DPH.

9. Dudova, I., Kocurkova, J. i Koutek, J. (2015). Early-onset anorexia nervosa in girls with Asperger syndrome. Journal of Neuropsychiatric Disease and Treatment, 11, 1639-1643.

10. Ćeranić, S. (2005). Poremećaji ishrane u djetinjstvu i mladosti. Radovi Filozofskog fakulteta, 209 - 220, Univerzitet u Istočnom Sarajevu.

11. Eisler, I., Dare, C., Hodes, M., Russell, G., Dodge, E., i D. Le Grange. 2000. Family therapy for adolescent anorexia nervosa: the results of a controlled comparison of two family interventions. Journal of Child Psychology and Psychiatry, 41, 727-736.

12. Eisler, I., Simic, M., Russel, G.F. i Dare, C. (2007). A randomised controlled treatment trial of two forms of family therapy in adolescent anorexia nervosa: a five-year follow-up. Journal of Child Psychology and Psychiatry, 48, 552-560.

13. Erić, Lj. i Čurčić, V. (1997). Adolescencija: identitetpsihopatologija - psihoterapija. KBC "Dr. Dragiša Mišović". Dedinje: IP “Žarko Abulj”.

14. Fairburn C. G, Welch, S. L, Doll, H. A., Davies, B. A., i O’Connor, M. E. (1997). Risk factors for bulimia nervosa. A community-based case-control study. Archives of General Psychiatry, 54, 509-517.

15. Gardner, D.M. i Garfinkel, P.E. (1997). Handbook of Treatment for Eating Disorders. The Guilford Press.

16. Harden, K.P., Mendle. J. i Kretsch, N. (2012). Environmental and genetic pathways between early pubertal timing and dieting in 
adolescence: Distinguishing between objective and subjective timing. Psychol Med, 42, 183-193.

17. Hotujac, Lj. i suradnici (2006). Psihijatrija (str. 219-223). Zagreb: Medicinska Naklada.

18. Jacobi, C., Paul, T., de Zwaan, M., Nutzinger, O., i D., Dahme, B. (2002). Specifity of Self- Concept Disturbances in Eating Disorders. Department of Psychology. Fachbereich University of Trier, Trier, Germany.

19. Kaplan, H.I. i Sadock L.B. (2000). Aetiology. In B. Bryant-Waught i R. Lask (Eds). Anorexia Nervosa and Related Eating Disorders in Childhood and Adolescence. East Sussex: Psychology Press Ltd.

20. Kaplan, H.I. i Sadock L.B. (1998). Priručnik kliničke psihijatrije. Jastrebarsko: Naklada Slap.

21. Klump, K.L., Burt, S.A., McGue, M. i Iacono, W.G. (2007). Changes in genetic and environmental influences on disordered eating across adolescence: A longitudinal twin study. Archives of General Psychiatry, 64, 1409-1415.

22. Klump, K.L., Burt, S.A., McGue, M., Iacono, W.G. i Wade, T.M. (2010). Age differences in genetic and environmental influences on weight and shape concerns. International Journal of Eating Disorders, 43, 679-688.

23. Klump, K.L. i Culbert, K.M. (2007). Molecular genetic studies of eating disorders: Current status and future directions. Current Directions in Psychological Science, 16, 37-41.

24. Klump, K.L., Culbert, K.M., Edler, C. i Keel, P.K. (2008). Ovarian hormones and binge eating: Exploring associations in community samples. Psychological Medicine, 38, 1749-1757.

25. Klump, K.L., Culbert, K.M., Slane, J.D., Burt, S.A., Sisk, C.L. i Nigg, J.T. (2012). The effects of puberty on genetic risk for disordered eating: Evidence for sex difference. Psychological Medicine, 42, 627-638.

26. Klump, K.L. i Gobrogge, K.L. (2005). A review and primer of molecular genetic studies of anorexia nervosa. International Journal of Eating Disorders, 37, 43-48.

27. Klump, K.L., Keel, P.K., Racine, S.E., Burt, S.A., Neale, M., Sisk, C.L., Boker, S. i Hu, J.Y. (2013). The interactive effects of estrogen and progesterone on chagnes in emotional eating across the menstrual cycle. Journal of Abnormal Psychology, 122, 131-137. 
28. Le Grange, D., i Eisler, I. (2009). Family interventions in adolescent anorexia nervosa. Child and Adolescent Psychiatric Clinics of North America, 18, 159-173.

29. Le Grange i Lock, J. (2005). The dearth of psychological treatment studies fork anorexia nervosa. International Journal of Eating Disorders, 37, 79-91.

30. Lock, J., Agras, W.S., Bryson, S. i Kraemer, H.C. (2005). A Comparison of Short- and Long-Term Family Therapy for Adolescent Anorexia Nervosa. Adolescent Psychiatry, 44, 632-649.

31. Lock, J., Le Grange, D., Agras, W.S. i Dare, C. (2001). Treatmen Manual for Anorexia Nervosa: A Family-Based Approach. New York: Guildford Publications, Inc.

32. Lock, J. (2011). Evaluation of Family treatment models for eating disorders. Current Opinion in Psychiatry 24, 274-290.

33. Matsumoto, H., Takei, N. i Kawai, M. (2001). Differences of symptoms and standardized weight index between patients with early - onset and late-onset anorexia nervosa. Acta Psychiatrica Scandinavica, 104, 66-71.

34. Mayer, J. D. (2001). A field guide to emotional intelligence. New York: Psychology Press.

35. McIntosh, V.V.W., Jordan, J., Carter, A.F., Luty, S.E., McKenzy, J.M., Bulik, C.M., Frampton, C.M.A. i Yojce, P.R. (2005). Three Psychotherapies for Anorexia Nervosa: A Randomized, Controlled Trial. The American Journal of Psychiatry, 162, 741-747.

36. Micali, N., Hagberg, K.W., Peterson, I. i Treasure, J.L. (2013). The incidence of eating disorders in the UK in 2000-2009 godine: findings from the General Practice Research Database. British Medicine Journal Open, 28, 3.

37. Monteleone, P., Treasure, J., Santonastaso, P., Favaro, A. i Braumbilla, F. (2005). Families of People with an Eating Disorder. Families and Mental Disorders: from burden to emprowement, 6, 113 - 127. Chichester: John Wiley i Sons.

38. Mrzola, N., Nasser, J.A., Hashim, S.A., Shih, P.B. I Kaye, W.H. (2013). Nutritional rehabilitation in anorexia nervosa: review of the literature and implications for treatment. BMC Psychiatry, 13-290.

39. Pike, K.M, Walsh, B.T, Vitousek, K., Wilson, G.T i Bauer, J. (2003). Cognitive behavior therapy in the posthospitalization treatment of anorexia nervosa. The American Journal of Psychiatry, 160, 2046-2049. 
40. Rhodes, P., Brown, J. i Madden, S. (2009). The Maudsley model of family-based treatment for anorexia nervosa. Journal of Marital and Family Therapy, 35, 181-189.

41. Scholz, M., Rix, M., Scholz, K., Gantchev, K., i Thomke, V. (2005). Multiple family therapy for anorexia nervosa: concepts, experiences and results. Journal of Family Therapy, 27, 132-141.

42. Schmidt, U. H., Troop, N. A., i Treasure, J. L. (1999). Stress and the onset of eating disorders: Correcting an "age-old" myth. International Journal of Eating Disorders, 25, 83-88.

43. Striegel-Moore, R.H., McMahon, R.P., Biro, F.M., Schreiber, G., Craford, P.B. i Voorhees, C. (2001). Exploring the relationship between timing of menarche and eating disorder symptoms in Black and White adolescent girls. International Journal of Eating Disorders, 30, 421-433.

44. Šeparović Lisak, M. i Marčinko, D. (2013). Uloga obiteljske psihoterapije u liječenju poremećaja hranjenja (66-75 str). U Marčinko i sur. Poremećaji hranjenja: od razumijevanja do liječenja. Zagreb: Medicinska Naklada.

45. Tadić, N. i sur. (2004). Psihoanalitička psihoterapija djece i mladih. Beograd: Naučna knjiga.

46. Taylor, M.J. i Cooper, P.J. (1986). Body size overestimation and depressed mood. British Journal of Clinical Psychology, 25, 153 154.

47. Treasure, J. L., i Holland, A. (1995). The Eating Disorders: Handbook of Theory, Treatment and Reasearch. Chichester: John Wiley i Sons.

48. Treasure, J., Schmidt, U., i Furth, E. V. (2003). Handbook of Eating Disorders. Chichester: John Wiley i Sons, Ltd.

49. Vidović, V. (1998). Anoreksija i bulimija: psihodinamski pogled na uzorke i posljedice bitke protiv tijela u adolescentica. Zagreb: M.A.K. Golden.

50. Vidović, V., Majić, G. i Begovac, I. (2008). Psihodinamski čimbenici u nastanku anoreksije nervoze i bulimije nervoze. Paediatria Croatica, 52, 106-100.

51. Vitousek, K. (1996). The current status of cognitive-behavioral models of anorexia nervosa and bulimia nervosa. U P. Salkovskis (Ed.), Frontiers of Cognitive Therapy (pp. 383-418). New York: Guilford Press. 
52. Vitousek, K., i Manke, F. (1994). Personality variables and disorders in anorexia nervosa and bulimia nervosa. Journal of Abnormal Psychology, 103, 137-147.

53. Vulić - Prtorić, A. (2007). Depresivnost u djece i adolescenata. Jastrebarsko: Naklada Slap.

54. Ward, A., Ramsey, R., Turnbull, S., Steele, M., Steele, H. i Treasure, J. (2001). Attachment in anorexia: a transgenerational perspective. British Journal Medicine Psychology, 74, 497-505.

55. Wenar, C. (2003). Razvojna psihopatologija i psihijatrija. Jastrebarsko: Naklada Slap. 
dr. sci. Vildana Aziraj-Smajić, clinical psychology specialist

\section{PSYCHOTHERAPEUTIC TREATMENT OF ANOREXIA NERVOSA IN THE ADOLESCENT AGE}

\section{Abstrakt}

Eating disorders in adolescence are a serious public health problem, because their treatment is lengthy, complex and demanding, while the outcome is most frequently uncertain. The objective of this paper is to provide a short review of the current findings about the application and effectiveness of psychotherapeutic treatment of adolescents diagnosed with anorexia nervosa. Before treatment is implemented, it is necessary to carry out a psychodiagnostic personality assessment of adolescents with the purpose of determining a dominant psychopathology. It has been established that the most frequently used methods in the treatment of this disorder are cognitive-behavioural, dialecticbehavioural, family, psychodynamic, cognitive-analytic and group psychotherapy. The essence of all therapeutic approaches is primarily reflected in the changing of self-destructive behaviours which put life at risk.

Considerable somatic complications demand active cooperation of psychotherapists with endocrinologists, internists and nutritionists. In accordance with their theoretical orientations, all psychotherapeutic treatments include specific mechanisms of change (cognitive restructuring, changes in interpersonal relationships, etc) which are determined in relation to the set therapeutic objectives. In certain cases it was established that psychotherapy can help alleviate and reduce the symptoms of comorbid disorders, with the symptomatology of the primary diagnosis of anorexia nervosa keeping its base. A majority of the current studies prove the effectiveness of family psychotherapy in treatment of anorexia nervosa in the adolescent age.

Key words: psychotherapy, eating disorders, anorexia nervosa 
الدكتورة فيلدانا آزيراي - سماييتش - أخصائية في علم النفس السريري'

\section{العلاج النفسي لمرض فقدان الشهية العصبي في سن المراهقة}

\section{الخلاصة}

تعتبر الاضطرابات المتعلقة بالتغذية في سن المراهقة مرضاً صحياً عاماً لأن علاجه

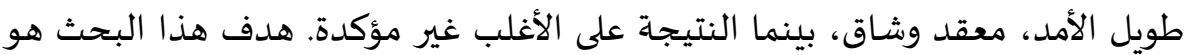

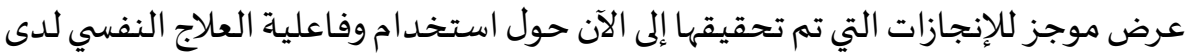

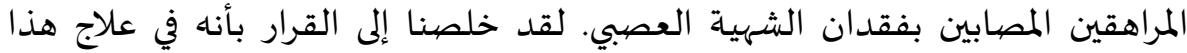
الاضطراب يتم استخدام العلاج المعرفي السلوكي، العلاج الجدلي السلوكي، العلاج العائلي، علاج التحليل النفسي، العلاج المعرفي التحليلي والعلاج الجماعي.

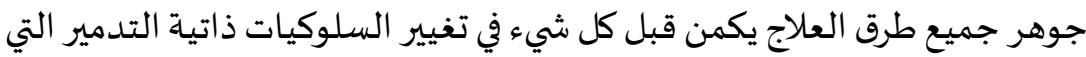
تهدد الحياة. وفقاً لجميع التوجهات النظرية فإن جميع طرق العلاج تستلزم آليات التغيير الخاصة (إعادة الهيكلة المعرفية، تغيير التعامل مع الآخرين، إلخ) والتي تتحدّد مقارنة

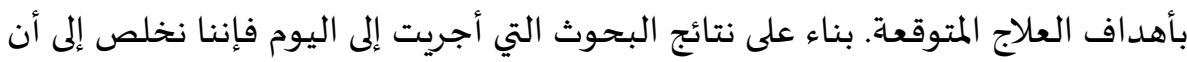
العلاج النفسي العائلي أكثر الطرق فاعلية في علاج فقدان الشهية العصبية العبي في سن المبات المراهقة.

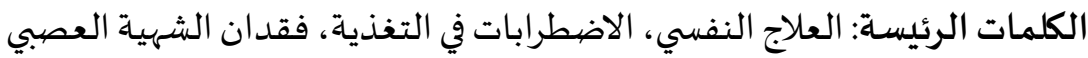

